\title{
Enzyme-Enhanced Extraction of Phenolic Compounds and Proteins from Flaxseed Meal
}

\author{
Bernardo Dias Ribeiro, Daniel Weingart Barreto, and Maria Alice Zarur Coelho \\ School of Chemistry, Federal University of Rio de Janeiro, Ilha do Fundão, 21945-970, Rio de Janeiro, RJ, Brazil \\ Correspondence should be addressed to Bernardo Dias Ribeiro; dias.bernardo@gmail.com
}

Received 21 August 2012; Accepted 11 September 2012

Academic Editors: B. Castiglioni, K. R. Davis, C. Scheckhuber, and A. Tiessen

Copyright (C) 2013 Bernardo Dias Ribeiro et al. This is an open access article distributed under the Creative Commons Attribution License, which permits unrestricted use, distribution, and reproduction in any medium, provided the original work is properly cited.

\begin{abstract}
Flaxseed (Linum usitatissimum) meal, the main byproduct of the flaxseed oil extraction process, is composed mainly of proteins, mucilage, and phenolic compounds. The extraction methods of phenolics either commonly employed the use of mixed solvents (dioxane/ethanol, water/acetone, water/methanol, and water/ethanol) or are done with the aid of alkaline, acid, or enzymatic hydrolysis. This work aimed at the study of optimal conditions for a clean process, using renewable solvents and enzymes, for the extraction of phenolics and proteins from flaxseed meal. After a screening of the most promising commercial preparations based on different carbohydrases and proteases, a central composite rotatable design and a mixture design were applied, achieving as optimal results a solution containing 6.6 and $152 \mathrm{~g} \mathrm{~kg}^{-1}$ meal of phenolics and proteins, respectively. The statistical approach used in the present study for the enzyme-enhanced extraction of phenolics and proteins from the major flaxseed byproduct was effective. By means of the sequential experimental design methodology, the extraction of such compounds was increased 10 -fold and 14-fold, when compared to a conventional nonenzymatic extraction.
\end{abstract}

\section{Introduction}

Flaxseed (Linum usitatissimum) meal is the main byproduct from the flaxseed oil extraction process, being primarily used as a ruminant feed. The meal is composed of three important fractions: proteins (over $300 \mathrm{~g} \mathrm{~kg}^{-1}$ ), which are rich in arginine and glutamine; amino acids that are very important in the prevention and treatment of heart diseases and in supporting the immune system; mucilage (approximate content of $80 \mathrm{~g} \mathrm{~kg}^{-1}$ ), which is a mixture of neutral arabinoxylans and rhamnogalacturonans, with good water-holding capacities and high viscosity; phenolic compounds, such as $p$-coumaric and ferulic acids, lignan secoisolariciresinol, which is presented glycosylated (Figure 1) and/or esterified with 3-hydroxy-3-methylglutaric acid to form oligomers. The content of secoisolariciresinol diglucoside in flaxseed is 2$3 \mathrm{~g} \mathrm{~kg}^{-1}$, and about $10-40 \mathrm{~g} \mathrm{~kg}^{-1}$ in defatted flaxseed powder [1-5].

In humans and animals, secoisolariciresinol is transformed by the anaerobic intestinal microflora into the mammalian lignans, enterolactone, and enterodiol, which are capable of binding at low levels to estrogen receptors. Additionally, these lignans have antioxidant, hypocholesterolemic, and antiatherosclerotic activities and inhibit the development of type 1 and type 2 diabetes, and mammary, prostatic, and colonic tumors [3, 6-9].

Lignans and total phenolic compounds are commonly extracted by using mixed solvents, such as dioxane/ethanol, water/acetone, water/methanol, and water/ethanol, followed by an ultrafiltration step for their recovery. Additionally, they can be extracted with the aid of alkaline or acid (e.g., hydrochloric acid) hydrolysis, but this method could be destructive for the target compounds whether too long heating periods or too high concentrations are used. Since flaxseed meal contains mucilage and proteins that could reduce access to the inner seed coat, enzymatic hydrolysis of these components could improve the release of phenolics and also release proteins which could aggregate value to the final product, depending on the application $[3,6,9-$ 12]. Furthermore, protein hydrolyzates could be applied as food additives, contributing for their functional properties [8]. 


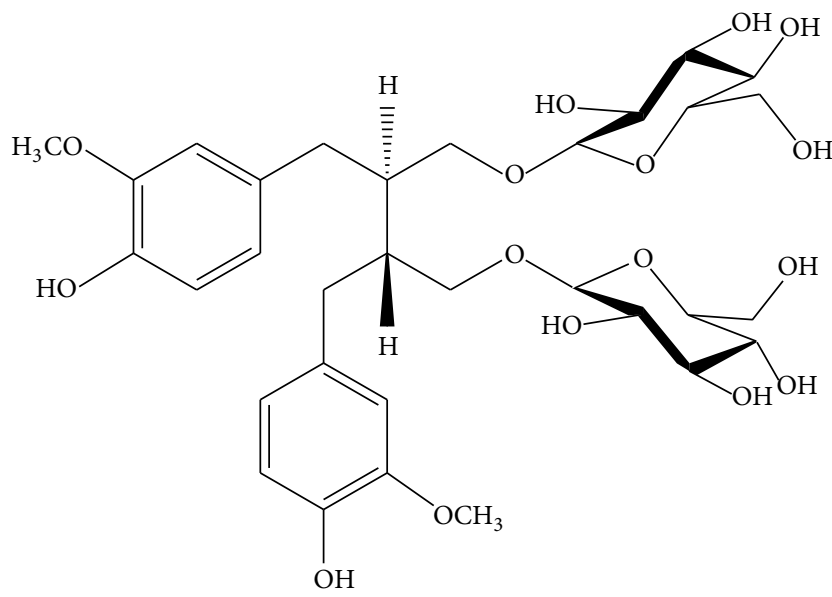

FIgURE 1: Lignan secoisolariciresinol diglucoside.

Therefore, the objective of this work was the development of a clean process, based on renewable solvents and enzymes (carbohydrases and proteases), for the extraction of phenolics and proteins from flaxseed meal, by using experimental design techniques.

\section{Materials and Methods}

2.1. Materials. The flaxseed meal used in this work was donated by Olvepin (Indústria de Óleos Vegetais Pindorama Ltda, Panambi, Brazil). The following enzymes' preparations were obtained from Novozymes Latin America (Araucaria, Brazil) and Vetec Química Fina Ltda (Duque de Caxias, Brazil).

(i) Ultrazym: $3400 \mathrm{FDU} 20^{\circ} \mathrm{C} \cdot \mathrm{mL}^{-1}$, density $1.2 \mathrm{~g} \cdot \mathrm{mL}^{-1}$, FDUs = Ferment Depectinization Units, enzyme quantity which depolymerizes $33.3 \mathrm{~mL}$ standard juice containing $0.4 \mathrm{~g} \cdot \mathrm{L}^{-1}$ pectin at $\mathrm{pH} 3.5,55^{\circ} \mathrm{C}$ in $2 \mathrm{~h}$.

(ii) Viscozyme: $100 \mathrm{FBG} \cdot \mathrm{g}^{-1}$, density $1.2 \mathrm{~g} \cdot \mathrm{mL}^{-1}$, FBG $=$ Fungal Beta-Glucanase Units, enzyme quantity which hydrolyzes beta-glucan to reducing sugars corresponding to $1 \mu \mathrm{mol}$ glicose per minute at $\mathrm{pH} 5.0$, $30^{\circ} \mathrm{C}$ during 30 minutes.

(iii) Proteases: Neutrase, Alcalase, Flavourzyme, Papain, Pepsin, and Pancreatin.

2.2. Analytical Methods. The phenolic compounds content was determined according to the Folin-Denis method [13], using tannic acid as standard. Soluble proteins content was determined according to the Lowry method [14], using bovine serum albumin as standard, whereas reducing sugars content was determined by the Somogyi method [15]. For the measurement of proteolytic activity, enzyme solution was added to an azocasein solution $\left(1 \mathrm{~g} \mathrm{~L}^{-1}\right)$ in universal buffer $\mathrm{pH} 6.0$, resulting in a final enzyme concentration of $0.5 \mathrm{~g} \cdot \mathrm{L}^{-1}$ (or $\mathrm{g} \cdot \mathrm{kg}^{-1}$ ) and maintained at $32^{\circ} \mathrm{C}$ for $20 \mathrm{~min}$. The reaction was stopped by the addition of a trichloroacetic acid solution $\left(200 \mathrm{~mL} \mathrm{~L}^{-1}\right)$, the samples were centrifuged, and then $\mathrm{KOH}$ solution $\left(280 \mathrm{~g} \cdot \mathrm{L}^{-1}\right)$ was added to the supernatant, with the absorbance at $428 \mathrm{~nm}$ registered [16]. All analyses were done in triplicate using a Shimadzu UV-1800 spectrophotometer.

2.3. Experimental Procedure. The first step for the process optimization was the screening of the effects of different hydrolytic enzymes acting on polysaccharides and proteins, allowing more phenolics and proteins extraction. Hence, in addition to monitoring phenolics and proteins contents, reducing sugar content was also evaluated which was associated with polysaccharide hydrolysis. For this extraction, two solvent compositions were evaluated: pure (distilled) water and ethanolic solution $\left(100 \mathrm{~mL} \mathrm{~L}^{-1}\right)$. This ethanol concentration was selected as the maximum which could be evaluated for the improvement of the components extraction, with no damages to enzyme activity [17]. For this set of experiments, the fixed conditions used were meal concentration, $0.2 \mathrm{~g} \mathrm{~mL}^{-1}$; temperature, $50^{\circ} \mathrm{C}$; time, $1.5 \mathrm{~h}$; agitation speed, $200 \mathrm{rpm}$. Enzyme concentrations added in each trial were $10 \mathrm{~mL} \mathrm{~L}^{-1}$ for Ultrazym, Viscozyme, and Alcalase, whereas lower charges were used for Neutrase (4.1 $\left.\mathrm{g} \mathrm{L}^{-1}\right)$, Flavourzyme $\left(3.5 \mathrm{~mL} \mathrm{~L}^{-1}\right)$, Papain $\left(7.5 \mathrm{~g} \mathrm{~L}^{-1}\right)$, Pancreatin $\left(14.5 \mathrm{~g} \mathrm{~L}^{-1}\right)$, and Pepsin $\left(20.7 \mathrm{~g} \mathrm{~L}^{-1}\right)$, according to their activities, so that, in all experiments where proteases were used, the proteolytic charge was the same. In the trials where Pepsin was used, the $\mathrm{pH}$ was adjusted to 3 , according to the recommendation of the supplier.

Once the most promising enzyme preparations were chosen, a central composite rotatable design (CCRD) was performed, considering ethanol concentration $\left(0-100 \mathrm{~mL} \cdot \mathrm{L}^{-1}\right)$, meal concentration $\left(0.05-0.20 \mathrm{~g} \cdot \mathrm{mL}^{-1}\right)$, and enzyme concentration $\left(0-20 \mathrm{~mL} \cdot \mathrm{L}^{-1}\right)$ as factors. The proportion between the three enzyme preparations used in these experiments was maintained constant (1/1/1).

The optimized conditions pointed out by the CCRD were used in the following set of experiments, which was a simplex centroid mixture design, in order to determine the optimal proportion between the three enzyme preparations $\left(0-20 \mathrm{~mL} \cdot \mathrm{L}^{-1}\right.$ for each one) for the release of phenolic compounds. All results from experimental designs were analyzed using the software Statistica 6.0.

\section{Results and Discussion}

3.1. Enzyme Screening. Due to different mechanisms of action towards substrates that can be presented by proteases, such as nucleophilic attack (e.g., serine and cysteine proteases) or acid/base catalysis (e.g., aspartic or metalloproteases) [18], an enzyme screening considering several proteolytic preparations was performed in order to compare their action on flaxseed meal (Table 1). Some authors used other proteases as ficin, thermolysin, and trypsin in the processing of proteins isolated from defatted flaxseed meal reaching 73 to $99 \%$ of peptides with a size below $1 \mathrm{kDa}$ [1921].

Both pectinases-based (Ultrazym) and hemicellulasesbased (Viscozyme) preparations presented a considerable action on mucilage hydrolysis, evidenced by the higher 
TABLE 1: Enzyme screening for hydrolysis of flaxseed meal.

\begin{tabular}{|c|c|c|c|c|c|c|c|}
\hline & Water $\left(\mathrm{mL} \cdot \mathrm{L}^{-1}\right)$ & $\mathrm{EtOH}\left(\mathrm{mL} \cdot \mathrm{L}^{-1}\right)$ & Enzyme & $\left(\mathrm{g} \cdot \mathrm{L}^{-1}\right.$ or $\left.\mathrm{mL} \cdot \mathrm{L}^{-1}\right)$ & Phenolics $\left(\mathrm{mg} \cdot \mathrm{g}^{-1}\right)$ & Proteins $\left(\mathrm{mg} \cdot \mathrm{g}^{-1}\right)$ & Sugars $\left(\mathrm{mg} \cdot \mathrm{g}^{-1}\right)$ \\
\hline 1 & 1000 & 0 & - & 0 & $0.90 \pm 0.05$ & $11.73 \pm 0.37$ & $0.51 \pm 0.05$ \\
\hline 2 & 900 & 100 & - & 0 & $0.83 \pm 0.04$ & $9.64 \pm 0.30$ & $0.65 \pm 0.05$ \\
\hline 3 & 1000 & 0 & Ultrazym & 10 & $4.27 \pm 0.09$ & $53.94 \pm 0.45$ & $23.27 \pm 0.30$ \\
\hline 4 & 900 & 100 & Ultrazym & 10 & $4.59 \pm 0.08$ & $67.14 \pm 0.51$ & $24.53 \pm 0.35$ \\
\hline 5 & 1000 & 0 & Viscozyme & 10 & $6.14 \pm 0.10$ & $54.18 \pm 0.42$ & $25.31 \pm 0.38$ \\
\hline 6 & 900 & 100 & Viscozyme & 10 & $4.46 \pm 0.08$ & $67.79 \pm 0.53$ & $23.96 \pm 0.46$ \\
\hline 7 & 1000 & 0 & Neutrase & 4.1 & $1.75 \pm 0.07$ & $29.55 \pm 0.45$ & $2.49 \pm 0.06$ \\
\hline 8 & 900 & 100 & Neutrase & 4.1 & $1.98 \pm 0.06$ & $33.19 \pm 0.41$ & $4.00 \pm 0.10$ \\
\hline 9 & 1000 & 0 & Alcalase & 10 & $2.99 \pm 0.09$ & $32.47 \pm 0.42$ & $3.15 \pm 0.08$ \\
\hline 10 & 900 & 100 & Alcalase & 10 & $2.47 \pm 0.05$ & $36.09 \pm 0.54$ & $2.39 \pm 0.04$ \\
\hline 11 & 1000 & 0 & Flavourzyme & 3.5 & $1.78 \pm 0.04$ & $30.21 \pm 0.21$ & $5.08 \pm 0.06$ \\
\hline 12 & 900 & 100 & Flavourzyme & 3.5 & $1.56 \pm 0.06$ & $22.94 \pm 0.25$ & $9.43 \pm 0.19$ \\
\hline 13 & 1000 & 0 & Papain & 7.5 & $2.13 \pm 0.07$ & $27.95 \pm 0.35$ & $3.52 \pm 0.07$ \\
\hline 14 & 900 & 100 & Papain & 7.5 & $1.26 \pm 0.04$ & $21.64 \pm 0.38$ & $6.30 \pm 0.12$ \\
\hline 15 & 1000 & 0 & Pepsin & 20.7 & $1.97 \pm 0.06$ & $32.21 \pm 0.42$ & $5.57 \pm 0.11$ \\
\hline 16 & 900 & 100 & Pepsin & 20.7 & $2.79 \pm 0.08$ & $36.45 \pm 0.57$ & $9.91 \pm 0.16$ \\
\hline 17 & 1000 & 0 & Pancreatin & 14.5 & $4.62 \pm 0.08$ & $41.04 \pm 0.70$ & $7.27 \pm 0.12$ \\
\hline 18 & 900 & 100 & Pancreatin & 14.5 & $3.63 \pm 0.09$ & $30.62 \pm 0.55$ & $9.50 \pm 0.14$ \\
\hline
\end{tabular}

release of phenolic compounds and proteins, generally improved in the presence of ethanol. Some authors reported the use of polysaccharide-degrading enzymes, alone or in combination, to enable the utilization of flaxseed meal as animal feed, lowering in $34.7 \%$ mucilage content with combination of cellulase, mannase, and pectinases [22], while others applied these enzymes and soaking with sodium bicarbonate solutions for the improvement of extraction and recovery of flaxseed proteins [23]. The authors showed similar results regarding protein recovery $(70 \%)$ when they used a seed concentration of $0.2 \mathrm{~g} \mathrm{~mL}^{-1}$, in a solution containing $0.01 \mathrm{M}$ acetate buffer, $\mathrm{pH} 4.0$ at $40^{\circ} \mathrm{C}$, and the preparation Viscozyme for $3 \mathrm{~h}$, and a treatment with $\mathrm{NaHCO}_{3} 0.10 \mathrm{M}$ for $12 \mathrm{~h}, 30^{\circ} \mathrm{C}$, using a ratio seed/solvent $1 / 10$.

Use of cellulases was also reported, after sequential extraction with $70 \mathrm{~mL} \mathrm{~L}^{-1}$ methanol during $16 \mathrm{~h}$ followed by $0.1 \mathrm{M}$ sodium hydroxide hydrolysis during $6 \mathrm{~h}$, for mucilage hydrolysis and observed improved release of phenolics from flaxseed hulls. The hull concentration used was $0.025 \mathrm{~g} \mathrm{~mL}^{-1}$, at $40^{\circ} \mathrm{C}$, for $6 \mathrm{~h}$ and $0.1 \mathrm{M}$ citrate-phosphate buffer $\mathrm{pH} 2.8$. Using these conditions, the maximum secoisolariciresinol concentration obtained was $40.75 \mathrm{mg} \cdot \mathrm{g}^{-1}$ [9]. In another work, the authors used cellulases only for the aid of the solubilization of flaxseed meal proteins by $0.5 \mathrm{M} \mathrm{NaOH}$ $[19,21]$. Whereas, another systems already have been tested without enzymes, using $700\left(\mathrm{~mL} \mathrm{~L}^{-1}\right)$ ethanol, at $40^{\circ} \mathrm{C}$ for $28 \mathrm{~h}$ achieved $89.75 \mathrm{mg} \mathrm{g}^{-1}$ of lignans from flaxseed meal [3], or using pressurized (5.2 $\mathrm{MPa}$ ) low polarity water at $170^{\circ} \mathrm{C}$ obtained $21 \mathrm{mg} \mathrm{g}^{-1}$ of lignans, $\mathrm{pH} 9$ with meal concentration of $0.01 \mathrm{~g} \mathrm{~mL}^{-1}$, and $225 \mathrm{mg} \mathrm{g}^{-1}$ of proteins using water at $160^{\circ} \mathrm{C}, 5.2 \mathrm{MPa}, \mathrm{pH}$ 9, and meal concentration of $0.005 \mathrm{~g} \mathrm{~mL}^{-1}$, during 3 to $7 \mathrm{~h}$ [24], or aided by nonthermal energies, as microwave and ultrasound, using $400\left(\mathrm{~mL} \mathrm{~L}^{-1}\right)$ ethanol for presoaking of defatted flour of flaxseed hulls with
$80 \mathrm{~W}$ ultrasonic treatment for $5 \mathrm{~min}$ and $130 \mathrm{~W}$ microwave irradiation during $90.5 \mathrm{~s}$ reaching $11.7 \mathrm{~g} \cdot \mathrm{kg}^{-1}$ of secoisolariciresinol [25].

Amongst the evaluated proteolytic preparations, it was observed that ethanol inhibited slightly the action of Pancreatin, Papain, and Flavourzyme. Despite that, the content of phenolic compounds and proteins was increased in comparison with the control conditions (without enzymes), with 5.1-fold and 3.5-fold increment, respectively. Although Pancreatin promoted the best results for phenolics release, the final solutions obtained (using both solvent compositions) presented undesired organoleptic characteristics. For this reason, Alcalase, which was the second best proteolytic preparation, was selected for further experiments.

3.2. Central Composite Design. The preparations Alcalase, Ultrazym, and Viscozyme were used for the CCRD, which allowed the determination of optimized conditions in terms of ethanol concentration in solvent, meal concentration, and enzyme concentration. Experimental results (Table 2) were analyzed in Statistica 6.0. For each response, the statistic models were adjusted in order to present the highest coefficient of determination $\left(R^{2}\right)$ with all terms statistically significant $(P$ value $<0.05)[26,27]$. Then, optimized conditions were calculated by response surface methodology using the global desirability approach. For this, each one of the three response variables was converted to individual desirability functions (which varies from 0 to 1 ), and then the global desirability function (objective function) was calculated as a geometric mean of all individual desirability functions [26].

The relevant terms were all three linear terms of factors, quadratic term of the ratio meal/solvent, and interaction between linear terms of ethanol concentration 
TABLE 2: Optimization of flaxseed meal hydrolysis by central composite design.

\begin{tabular}{|c|c|c|c|c|c|c|}
\hline Assays & $\mathrm{EtOH}\left(\mathrm{mL} \cdot \mathrm{L}^{-1}\right)$ & Meal/solvent $\left(\mathrm{g} \cdot \mathrm{mL}^{-1}\right)$ & Enzyme $\left(\mathrm{mL} \cdot \mathrm{L}^{-1}\right)$ & Phenolics $\left(\mathrm{mg} \cdot \mathrm{g}^{-1}\right)$ & Proteins $\left(\mathrm{mg} \cdot \mathrm{g}^{-1}\right)$ & Sugars $\left(\mathrm{mg}^{\circ} \mathrm{g}^{-1}\right)$ \\
\hline 1 & 20 & 0.080 & 4 & 5.52 & 186.97 & 56.28 \\
\hline 2 & 20 & 0.080 & 16 & 5.46 & 235.46 & 79.48 \\
\hline 3 & 20 & 0.170 & 4 & 3.82 & 102.27 & 25.85 \\
\hline 4 & 20 & 0.170 & 16 & 5.77 & 118.86 & 28.16 \\
\hline 5 & 80 & 0.080 & 4 & 6.44 & 180.77 & 61.03 \\
\hline 6 & 80 & 0.080 & 16 & 7.55 & 221.66 & 66.94 \\
\hline 7 & 80 & 0.170 & 4 & 0.80 & 30.62 & 9.16 \\
\hline 8 & 80 & 0.170 & 16 & 4.22 & 78.04 & 19.52 \\
\hline 9 & 0 & 0.125 & 10 & 8.06 & 141.65 & 39.79 \\
\hline 10 & 100 & 0.125 & 10 & 3.69 & 105.22 & 35.26 \\
\hline 11 & 50 & 0.050 & 10 & 1.61 & 298.40 & 83.32 \\
\hline 12 & 50 & 0.200 & 10 & 1.75 & 47.41 & 15.01 \\
\hline 13 & 50 & 0.125 & 0 & 0.50 & 41.08 & 4.56 \\
\hline 14 & 50 & 0.125 & 20 & 9.75 & 171.04 & 41.07 \\
\hline $15(\mathrm{C})$ & 50 & 0.125 & 10 & 6.01 & 136.67 & 39.53 \\
\hline $16(\mathrm{C})$ & 50 & 0.125 & 10 & 5.93 & 137.85 & 38.02 \\
\hline $17(\mathrm{C})$ & 50 & 0.125 & 10 & 6.25 & 141.05 & 39.74 \\
\hline
\end{tabular}

TABLE 3: Optimization of enzyme ratio in the flaxseed meal hydrolysis by mixture design.

\begin{tabular}{|c|c|c|c|c|c|c|}
\hline Assays & $\% \mathrm{Pe}$ & $\% \mathrm{H}$ & $\% \operatorname{Pr}$ & Phenolics $\left(\mathrm{mg} \cdot \mathrm{g}^{-1}\right)$ & Proteins $\left(\mathrm{mg} \cdot \mathrm{g}^{-1}\right)$ & Sugars $\left(\mathrm{mg} \cdot \mathrm{g}^{-1}\right)$ \\
\hline 1 & 1.00 & 0.00 & 0.00 & 0.55 & 115.69 & 37.14 \\
\hline 2 & 0.00 & 1.00 & 0.00 & 5.30 & 179.01 & 44.50 \\
\hline 3 & 0.00 & 0.00 & 1.00 & 7.10 & 114.52 & 11.90 \\
\hline 4 & 0.50 & 0.50 & 0.00 & 5.35 & 161.72 & 43.70 \\
\hline 5 & 0.50 & 0.00 & 0.50 & 8.87 & 159.00 & 31.40 \\
\hline 6 & 0.00 & 0.50 & 0.50 & 9.56 & 164.75 & 41.43 \\
\hline 7 & 0.67 & 0.17 & 0.17 & 6.72 & 158.73 & 43.61 \\
\hline 8 & 0.17 & 0.67 & 0.17 & 6.17 & 149.25 & 37.25 \\
\hline 9 & 0.17 & 0.17 & 0.67 & 5.72 & 144.25 & 34.16 \\
\hline 10 & 0.33 & 0.33 & 0.33 & 8.45 & 175.50 & 41.16 \\
\hline
\end{tabular}

Pe: pectinases (Ultrazym).

H: hemicellulase (Viscozyme).

Pr: protease (Alcalase).

and ratio meal/solvent with adjusted $R^{2}$ of $0.613,0.937$, and 0.883 for phenolic compounds, proteins, and reducing sugars, respectively. The multiresponse optimization was programmed with focus on the maximization of the phenolic compounds' extraction, so that the other response variables were maintained at intermediate values. With this scenario, the global optimal conditions were pure water as solvent (ethanol concentration equal to $0 \mathrm{mLL}^{-1}$ ); meal concentration, $0.152 \mathrm{~g} \mathrm{~mL}^{-1}$; total enzyme concentration (the sum of the three preparations, equally added), $20 \mathrm{~mL} \mathrm{~L}^{-1}$. These conditions obtained were not surprising since at Table 1 can be verified, in presence of $100 \mathrm{~mL} \cdot \mathrm{L}^{-1}$ ethanol, the extraction of phenolic compounds had been decreased when using Viscozyme and Alcalase, and with a high enzyme content, the proteins and polysaccharides were faster degraded, and more phenolic compounds released from flaxseed meal.
3.3. Mixture Design. The optimized conditions pointed out by the desirability approach were considered for the mixture design, where different proportions between the preparations Ultrazym (Pe, pectinase), Viscozyme ( $\mathrm{H}$, hemicellulase), and Alcalase (Pr, protease) were investigated (Table 3). Using the modified full cubic model, the parameters' coefficients which were statistically significant were linear terms of hemicellulase and protease, and the interaction between pectinase and protease with adjusted $R^{2}$ 0.761. Focusing on maximizing the phenolic compounds content $\left(\mathrm{mg} \cdot \mathrm{g}^{-1}\right)$, the optimized enzyme formulation for use in phenolics extraction from flaxseed meal should contain $6.9 \mathrm{~mL} \mathrm{~L}^{-1}$ of Ultrazym and $3.1 \mathrm{~mL} \mathrm{~L}^{-1}$ of Alcalase (Figure 2). Statistical analysis indicated that, with this optimized conditions, hemicellulases (present in the preparation Viscozyme) were not necessary. Phenolics, proteins, and reducing sugars 


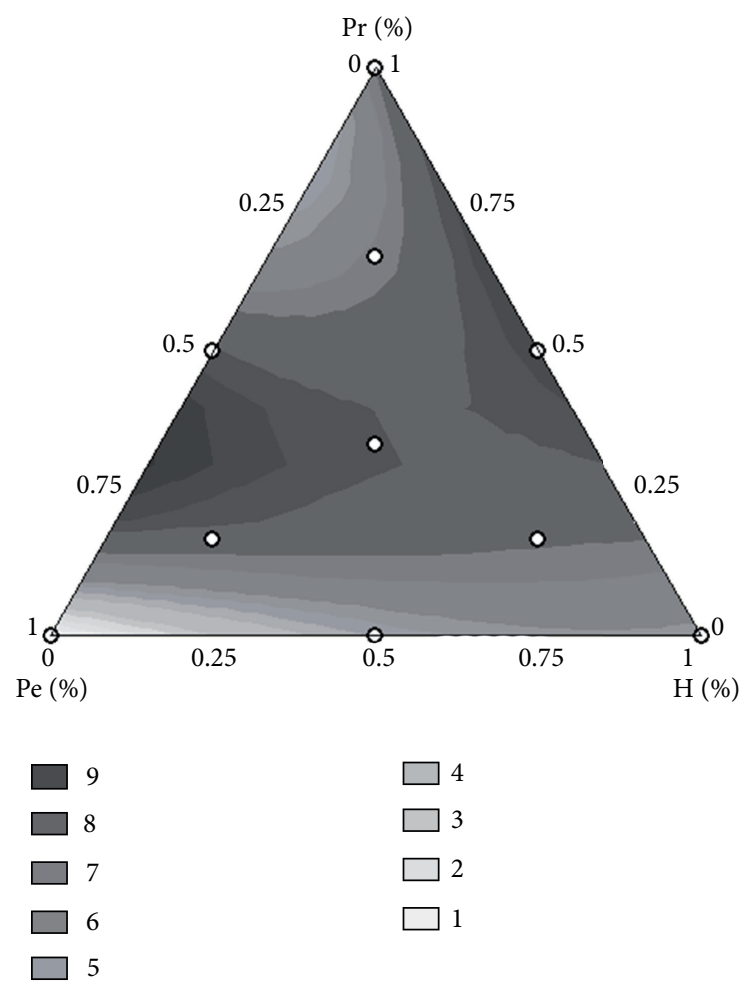

FIGURE 2: Response surface to the enzyme formulation for optimization of enzymatic extraction of phenolics. Pe: pectinases (Ultrazym), $\mathrm{H}$ : hemicellulase (Viscozyme), Pr: protease (Alcalase).

contents predicted in the optimized conditions were 6.6, 152, and $25.4 \mathrm{mg} \mathrm{g}^{-1}$, respectively.

When compared to the enzyme charges used in the former design, the volumes of both enzyme preparations were reduced, without significant loss in the recovery of the target compounds. Therefore, the use of a mixture design subsequently to a CCRD showed important improvement in the process for extraction of phenolics and proteins from flaxseed meal.

\section{Conclusion}

The use of several commercial enzyme preparations for the extraction of phenolics and proteins from the major flaxseed byproduct, flaxseed meal, was investigated. Two carbohydrase-based preparations (Ultrazym and Viscozyme) and an alkaline protease-based preparation (Alcalase) were used in a central composite rotatable design, where the optimal conditions pointed out were meal concentration of $0.152 \mathrm{~g} \mathrm{~mL}^{-1}$ and total enzyme concentration of $20 \mathrm{~mL} \mathrm{~L}^{-1}$, in a system containing only pure (distilled) water as solvent. When evaluated in a simplex centroid mixture design, the optimal charges of the enzymes were $6.9 \mathrm{~mL} \mathrm{~L}^{-1}$ for Ultrazym and $3.1 \mathrm{~mL} \mathrm{~L}^{-1}$ for Alcalase, thus reduced as compared to the former optimization. At the end of the sequential optimization, the concentrations of phenolic compounds and proteins in the hydrolyzates were increased 10-fold and 14fold, respectively, in comparison to the control (without the addition of enzymes) experiment. The process proposed in the present study is a promising and alternative technology for the recovery of valuable components from an agricultural byproduct, meeting sustainability criteria due the use of a green solvent and renewable catalysts.

\section{Acknowledgments}

The authors acknowledge the financial support from The Brazilian Council for Research $(\mathrm{CNPq})$ and The Rio de Janeiro State Foundation for Science and Technology (FAPERJ).

\section{References}

[1] B. D. Oomah, "Flaxseed as a functional food source," Journal of the Science of Food and Agriculture, vol. 81, no. 9, pp. 889-894, 2001.

[2] J. Warrand, P. Michaud, L. Picton et al., "Structural investigations of the neutral polysaccharide of Linum usitatissimum L. seeds mucilage," International Journal of Biological Macromolecules, vol. 35, no. 3-4, pp. 121-125, 2005.

[3] Z. S. Zhang, D. Li, L. J. Wang et al., "Optimization of ethanolwater extraction of lignans from flaxseed," Separation and Purification Technology, vol. 57, no. 1, pp. 17-24, 2007.

[4] R. Naran, G. Chen, and N. C. Carpita, "Novel rhamnogalacturonan I and arabinoxylan polysaccharides of flax seed mucilage," Plant Physiology, vol. 148, no. 1, pp. 132-141, 2008.

[5] Y. Xu, C. Hall III, and C. Wolf-Hall, "Antifungal activity stability of flaxseed protein extract using response surface methodology," Journal of Food Science, vol. 73, no. 1, pp. M9-M14, 2008.

[6] C. Eliasson, A. Kamal-Eldin, R. Andersson, and P. Åman, "High-performance liquid chromatographic analysis of secoisolariciresinol diglucoside and hydroxycinnamic acid glucosides in flaxseed by alkaline extraction," Journal of Chromatography $A$, vol. 1012, no. 2, pp. 151-159, 2003.

[7] W. Zhang, X. Wang, Y. Liu et al., "Dietary flaxseed lignan extract lowers plasma cholesterol and glucose concentrations in hypercholesterolaemic subjects," British Journal of Nutrition, vol. 99, no. 6, pp. 1301-1309, 2008.

[8] K. Mueller, P. Eisner, Y. Yoshie-Stark, R. Nakada, and E. Kirchhoff, "Functional properties and chemical composition of fractionated brown and yellow linseed meal (Linum usitatissimum L.)," Journal of Food Engineering, vol. 98, no. 4, pp. 453-460, 2010.

[9] S. Renouard, C. Hano, C. Corbin et al., "Cellulase-assisted release of secoisolariciresinol from extracts of flax (Linum usitatissimum) hulls and whole seeds," Food Chemistry, vol. 122, no. 3, pp. 679-687, 2010.

[10] N. D. Westcott and D. Paton, "A complex containing lignan, phenolic and aliphatic substances from flax and process for preparing," WO Patent 00/78771 A1, 2000.

[11] T. A. Dobbins and D. B. Wiley, "Process for recovering secoisolariciresinol diglycoside from defatted flaxseed," US Patent 6806356 B2, 2004.

[12] M. Puri, D. Sharma, and C. J. Barrow, "Enzyme-assisted extraction of bioactives from plants," Trends in Biotechnology, vol. 30, pp. 37-44, 2011.

[13] P. G. Waterman and S. Mole, Analysis of Phenolic Plant Metabolites, Blackwell Scientific Publications, Oxford, UK, 1994. 
[14] O. H. Lowry, N. J. Rosebrough, A. L. Farr, and R. J. Randall, "Protein measurement with the Folin phenol reagent," The Journal of biological chemistry, vol. 193, no. 1, pp. 265-275, 1951.

[15] M. Somogyi, "Notes on sugar determination," The Journal of Biological Chemistry, vol. 195, pp. 19-23, 1952.

[16] P. F. F. Amaral, Produção de Lipase de Yarrowia Lipolytica em Biorreator Multifásico, Editora Edgard Blucher Ltda, São Paulo, Brazil, 1st edition, 2010.

[17] H. Chen and S. Jin, "Effect of ethanol and yeast on cellulase activity and hydrolysis of crystalline cellulose," Enzyme and Microbial Technology, vol. 39, no. 7, pp. 1430-1432, 2006.

[18] R. Beynon and J. S. Bond, Proteolytic Enzymes, a Practical Approach, Oxford University Press, Oxford, UK, 2nd edition, 2001.

[19] C. C. Udenigwe, Y. S. Lin, W. C. Hou, and R. E. Aluko, "Kinetics of the inhibition of renin and angiotensin I-converting enzyme by flaxseed protein hydrolysate fractions," Journal of Functional Foods, vol. 1, no. 2, pp. 199-207, 2009.

[20] C. C. Udenigwe, A. P. Adebiyi, A. Doyen, H. Li, L. Bazinet, and R. Aluko, "Low molecular weight flaxseed protein-derived arginine-containing peptides reduced blood pressure of spontaneously hypertensive rats faster than amino acid form of arginine and native flaxseed protein," Food Chemistry, vol. 132, pp. 468-475, 2012.

[21] C. C. Udenigwe, Y. L. Lu, C. H. Han, W. C. Hou, and R. E. Aluko, "Flaxseed protein-derived peptide fractions: antioxidant properties and inhibition of lipopolysaccharide-induced nitric oxide production in murine macrophages," Food Chemistry, vol. 116, no. 1, pp. 277-284, 2009.

[22] B. A. Slominski, X. Meng, L. D. Campbell, W. Guenter, and O. Jones, "The use of enzyme technology for improved energy utilization from full-fat oilseeds. Part II: flaxseed," Poultry Science, vol. 85, no. 6, pp. 1031-1037, 2006.

[23] P. K. J. P. D. Wanasundara and F. Shahidi, "Removal of flaxseed mucilage by chemical and enzymatic treatments," Food Chemistry, vol. 59, no. 1, pp. 47-55, 1997.

[24] C. H. L. Ho, J. E. Cacace, and G. Mazza, "Extraction of lignans, proteins and carbohydrates from flaxseed meal with pressurized low polarity water," LWT-Food Science and Technology, vol. 40, no. 9, pp. 1637-1647, 2007.

[25] W. Zhang and S. Xu, "Microwave-assisted extraction of secoisolariciresinol diglucoside from flaxseed hull," Journal of the Science of Food and Agriculture, vol. 87, no. 8, pp. 1455-1462, 2007.

[26] V. Calado and D. C. Montgomery, Planejamento de Experimentos Usando o Statistica, E-papers Serviços Editoriais, Rio de Janeiro, Brazil, 2003.

[27] M. I. Rodrigues and A. F. Iemma, Planejamento De Experimentos e Otimização De Processos, Casa do Pão Editora, 2005. 

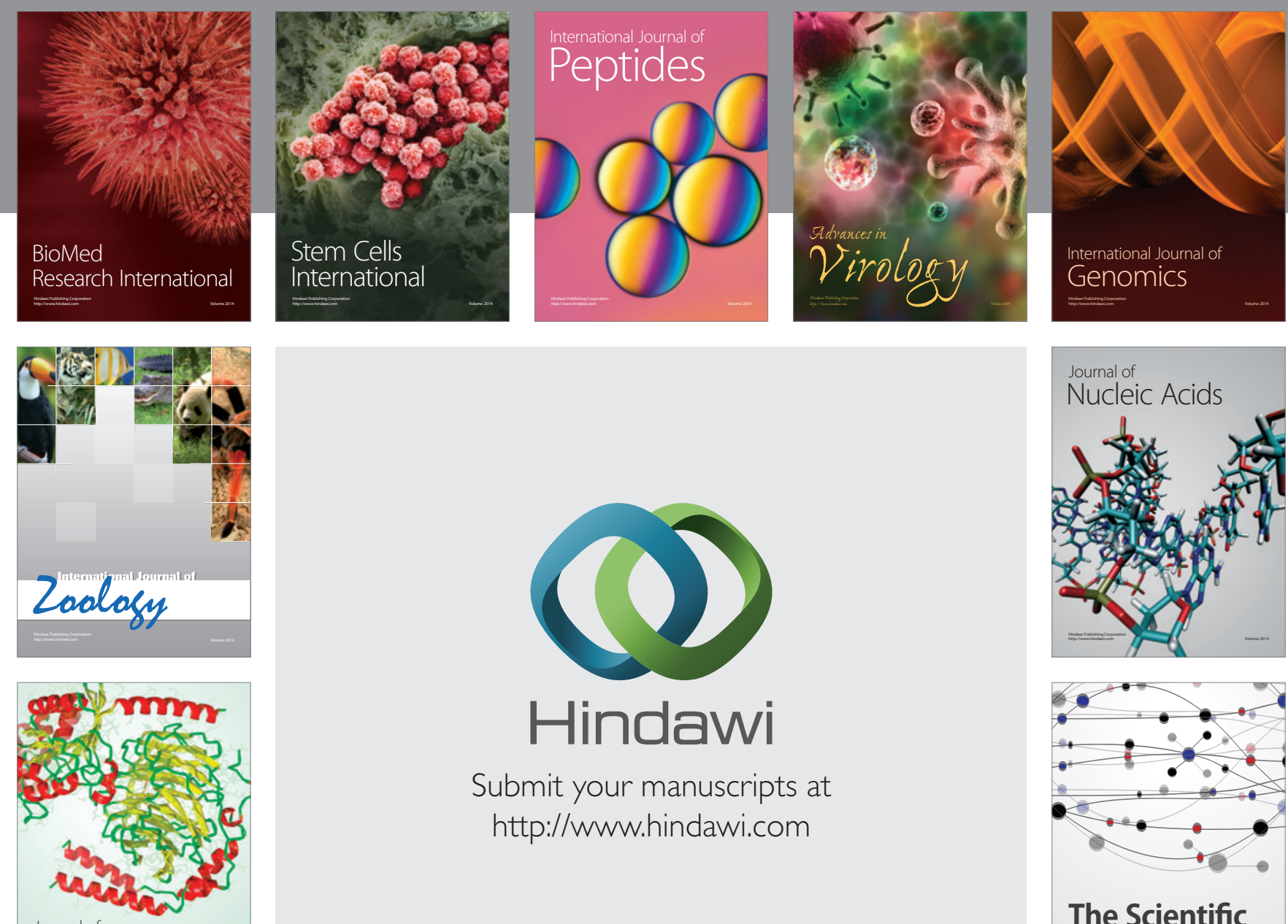

Submit your manuscripts at

http://www.hindawi.com

Journal of
Signal Transduction
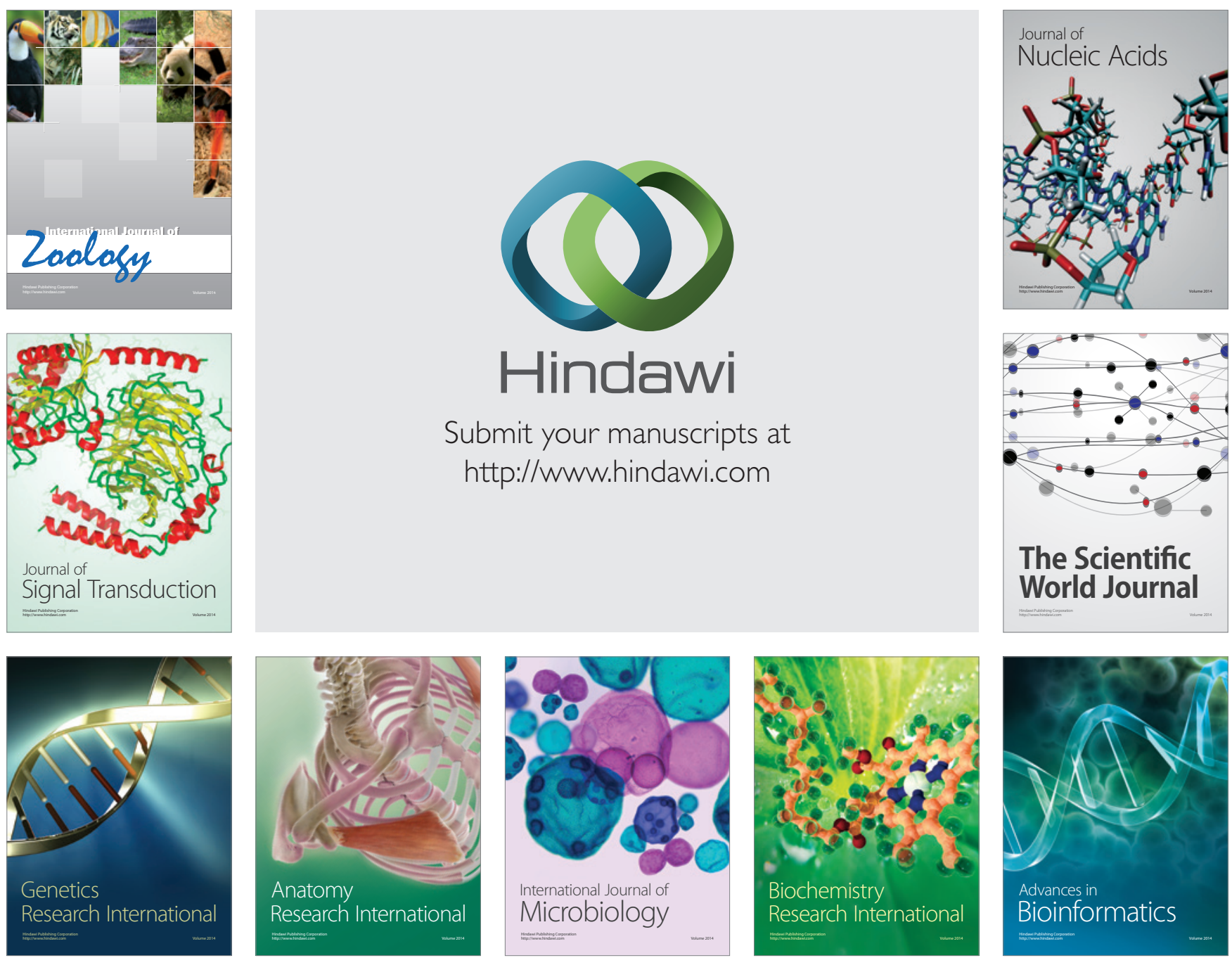

The Scientific World Journal
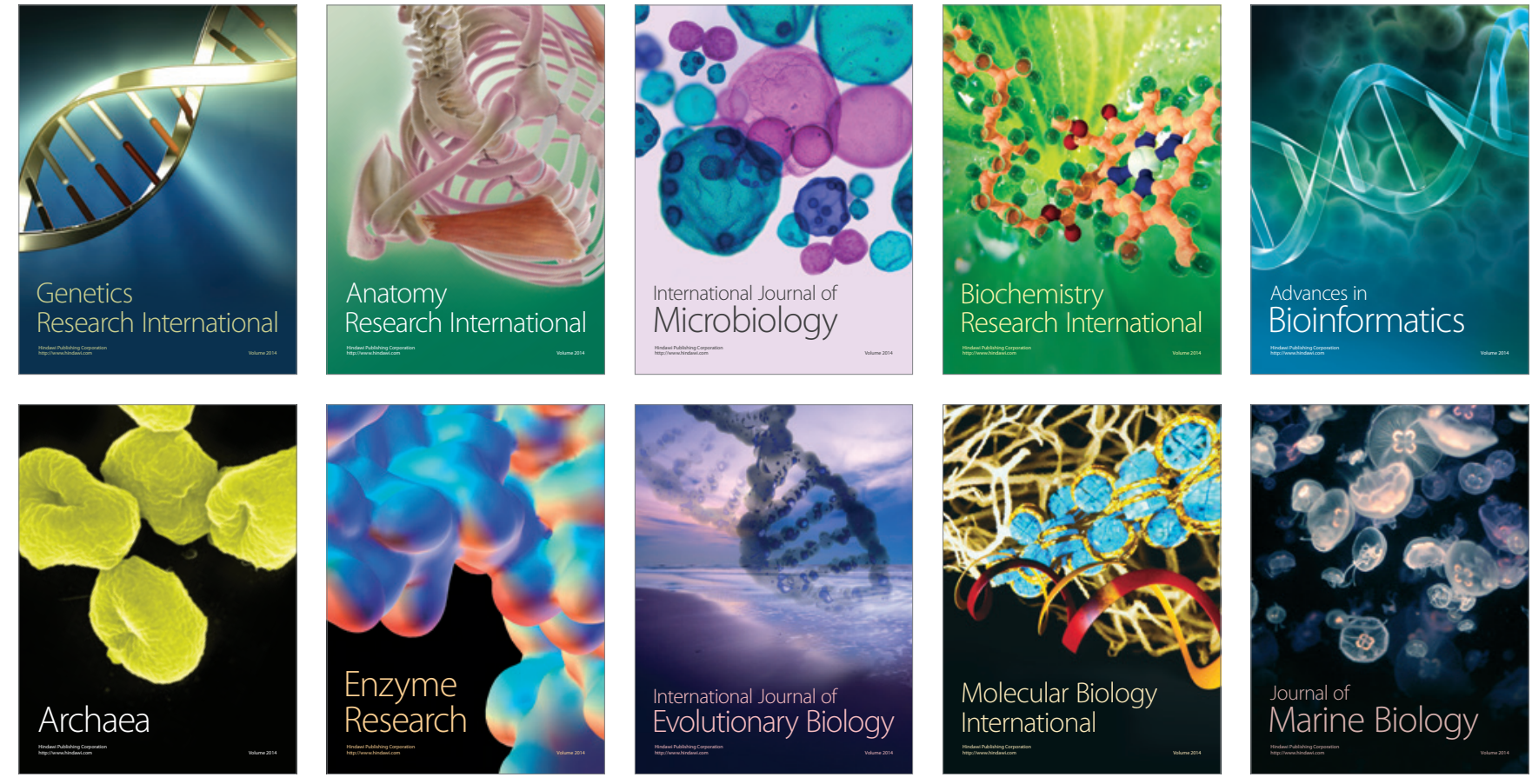